\title{
HUBUNGAN KEPATUHAN MINUM TABLET FE DENGAN ANEMIA IBU HAMIL
}

\author{
Yustina Ananti ${ }^{\star 1}$, Muthmainah ${ }^{2}$ \\ Program Studi D3 Kebidanan, STIKes Guna Bangsa, Yogyakarta \\ e-mail: *1 yustina.ananti@yahoo.com , ${ }^{2}$ muth.malik@ymail.com
}

\begin{abstract}
Background : Anemia in pregnant women is a national problem. In Indonesia, the incidence of anmia in pregnancy is quite high. Anemia prevention program does is provide iron tablet that preparations Fe. How to consume tablets Fe followed by respondents as important to follow the advice given by the researchers then the tendency will increase in hemoglobin levels as expected.
\end{abstract}

Objective: Given the relationship between adherence Fe tablets in pregnant women with anemia Puskesmas Grabag II Magelang regency.

Methods: This study is a correlational research analytic, using a cross- sectional survey design. The sampling technique used was purposive sample of the number of samples in this study were 134 respondents.

Results : There was a relationship adherence Fe tablets with maternal anemia status in Puskesmas Grabag II Magelang regency with $p$ value of $0.000(0.000<0.05)$ and the relationship is strong enough that the value of the Contingency Coefficient 0.556 .

Conclusion : There is a relationship adherence Fe tablets with maternal anemia status.

\section{Keywords : Compliance, Tablets Fe, Maternal Anemia}

\section{PENDAHULUAN}

Angka Kematian Ibu (AKI) bersama dengan Angka Kematian Bayi (AKB) senantiasa menjadi indikator keberhasilan pembangunan pada sektor kesehatan. Hasil Survei Dasar Kesehatan Indonesia (SDKI) tahun 2007 menyebutkan bahwa AKI untuk periode 5 tahun sebelum survey (2003-2007) sebesar 228/100.000 kelahiran hidup. Angka ini turun dibandingkan AKI hasil SDKI tahun 20022003 yaitu mencapai 307/100.000 kelahiran hidup. $^{1}$

Angka kematian ibu Provinsi Jawa Tengah tahun 2012 berdasarkan laporan dari kabupaten/kota sebesar $116,34 / 100.000$ kelahiran hidup, mengalami peningkatan bila dibandingkan dengan AKI pada tahun 2011 sebesar $116,01 / 100.000$ kelahiran hidup. Kematian sebesar $24,74 \%$ terjadi pada waktu hamil, $17,33 \%$ pada waktu persalinan dan $57,93 \%$ kematian maternal terjadi pada waktu nifas. Sementara berdasarkan kelompok umur, kejadian kematian maternal terbanyak adalah pada usia produktif (20-34 tahun) sebesar 66,96\%, kemudian pada kelompok umur $>35$ tahun sebesar $26,67 \%$ dan pada kelompok umur $<20$ tahun sebesar $6,37 \%$. $^{2}$

Angka Kematian lbu (AKI) mencerminkan risiko yang dihadapi ibuibu selama kehamilan dan melahirkan yang dipengaruhi oleh status gizi ibu, keadaan sosial ekonomi, keadaan 
kesehatan yang kurang baik menjelang kehamilan, kejadian berbagai komplikasi pada kehamilan dan kelahiran, tersedianya dan penggunaan fasilitas pelayanan kesehatan termasuk pelayanan prenatal dan obstetrik. Tingginya angka kematian ibu menunjukkan keadaan sosial ekonomi yang rendah dan fasilitas pelayanan kesehatan termasuk pelayanan prenatal dan obstetri yang rendah pula. ${ }^{2}$

Anemia ditandai dengan rendahnya konsentrasi hemoglobin $(\mathrm{Hb})$ atau hematocrit nilai ambang batas (referensi) yang disebabkan oleh rendahnya produksi sel darah merah (eritrosit) dan Hemoglobin $(\mathrm{Hb}), \quad$ meningkatnya kerusakan eritrosit (hemolysis) atau kehilangan darah yang berlebihan. Defisiensi $\mathrm{Fe}$ berperan besar dalam kejadian anemia, namun defisiensi zat gizi lainnya, kondisi non gizi, dan kelainan genetic (herediter) juga memainkan peran terhadap anemia. ${ }^{3}$

Anemia pada ibu hamil merupakan masalah nasional. Di Indonesia angka kejadian anemia dalam kehamilan cukup tinggi. Hasil survei anemia ibu hamil pada 15 Kabupaten/Kota pada tahun 2010 menunjukkan bahwa prevalensi anemia di Jawa Tengah adalah 78,6\%, angka ini masih lebih tinggi dari angka nasional yakni 71,2\% (Dinkes Jateng, 2010). Anemia dalam kehamilan adalah kondisi ibu dengan kadar hemoglobin di bawah $11 \%$ pada trimester 1 dan 3 atau kadar < $10,5 \%$ pada trimester $2 .{ }^{4}$

Program penanggulangan anemia yang dilakukan adalah memberikan tablet tambah darah yaitu preparat Fe yang bertujuan untuk menurunkan angka anemia pada balita, ibu hamill, ibu nifas, remaja putri, dan WUS (Wanita Usia Subur). Penanggulangan anemi pada ibu hamil dilaksanakan dengan memberikan 90 tablet Fe kepada ibu hamil selama periode kehamilannya (Dinkes Provinsi Jawa Tengah, 2012). Cakupan ibu hamil mendapatkan 90 tablet $\mathrm{Fe}$ di Indonesia menurut Kemenkes RI (2012) sebanyak $83,3 \%$, sedangkan cakupan ibu hamil mendapat 90 tablet $\mathrm{Fe}$ di Provinsi Jawa Tengah pada tahun 2012 sebesar 91,77\% mengalami peningkatan bila dibandingkan dengan pencapaian tahun 2011 $(89,39 \%)^{2}$
Upaya penanggulangan anemia gizi besi pada ibu hamil dilakukan melalui peningkatan cakupan suplementasi tablet besi. Upaya lain yang dapat dilakukan dengan memperhatikan pola konsumsi ibu hamil yang harus tetap mengacu pada pola makan sehat dan seimbang yang terdapat dalam pesan umum gizi seimbang (PUGS). Pengaturan makan pada ibu hamil bukan pada jumlah atau kuantitas melainkan pada kualitas atau komposisi zat-zat gizi, sebab faktor ini lebih efektif dan fungsional untuk kesehatan ibu dan janinnya. Misalnya untuk meningkatkan konsumsi bahan makanan tinggi besi seperti susu, daging, dan sayuran hijau atau buah. ${ }^{5}$

Wanita hamil merupakan kelompok yang diprioritaskan untuk memperoleh suplemen zat besi. Karena ibu hamil mentransportasi darah ke janin dan plasenta. Oleh karena itu salah satu upaya pemerintah yaitu mengambil langkah untuk pemberian zat besi melalui puskesmas, posyandu dan klinik untuk mengurangi kejadian anemia pada ibu hamil. Ditekankan juga bahwa gizi ibu hamil harus diperhatikan dan ibu hamil perlu memeriksakan kehamilan secara teratur. ${ }^{6}$ Gibney, et.al. (2009) memastikan bahwa distribusi suplemen zat besi dalam jumlah yang adekuat dan kepatuhan ibu hamil terhadap program pengobatan merupakan faktor yang mempengaruhi keberhasilan program tersebut. ${ }^{7}$

Program pemberian tablet zat besi pada ibu hamil sudah dijalankan sejak tahun 1970, namun masih terdapat beberapa kasus yang disebabkan karena anemia pada masa kehamilan. Hanya sedikit wanita hamil dinegara berkembang seperti di Indonesia yang dapat memenuhi kebutuhan zat besi selama kehamilan melalui makanan sehari-hari, karena sumber utama zat besi yang mudah diserap oleh tubuh (besi heme) yaitu protein hewani seperti ikan dan daging relatif mahal harganya dan belum sepenuhnya terjangkau oleh masyarakat. Walaupun terdapat sumber makanan nabati yang kaya zat besi seperti sayuran hijau dan kacang-kacangan, namun zat besi dalam makanan tersebut lebih sulit penyerapannya. Oleh karena itu program pemberian suplementasi tablet zat besi 
selama kehamilan merupakan salah satu alternatif untuk mengatasi anemia. ${ }^{8}$ Cara mengkonsumsi tablet $\mathrm{Fe}$ penting dipatuhi oleh responden karena dengan mengikuti anjuran yang disampaikan oleh peneliti maka kecenderungan peningkatan kadar hemoglobin akan sesuai dengan yang diharapkan. ${ }^{6}$

Persentase ibu yang melaporkan minum tablet Fe berdasarkan jumlah hari minum di Indonesia yaitu, minum selama 30 hari hanya 36,3 persen, yang minum 31-59 hari hanya 2,8 persen, minum $60-89$ hari berjumlah 8,3 persen dan ibu hamil yang minum tablet $\mathrm{Fe}$ selama 90 hari sebanyak 18 persen $^{9}$ dan sekitar $50 \%$ dari kematian di negara-negara berkembang dilatarbelakangi oleh anemia defisiensi besi.

Jumlah ibu hamil di Kabupaten Magelang sampai bulan Maret 2013 sebanyak 5.661 ibu hamil dan sebanyak $1.223(21,60 \%)$ ibu hamil mengalami anemia. Puskesmas Grabag II merupakan salah satu sarana kesehatan yang ada di Kecamatan Grabag Kabupaten Magelang. Jumlah ibu hamil sampai pada bulan Juni 2013 sebanyak 477 ibu hamil dengan 90 $(18,86 \%)$ ibu hamil mengalami anemia. Dari survei pendahuluan yang peneliti lakukan pada ibu hamil yang datang memeriksakan kehamilan di Puskesmas Grabag II berjumlah 15 orang hanya 5 $(33,3 \%)$ orang yang menghabiskan tablet Fe satu bungkus dalam waktu 30 hari, dan hal ini diperkuat oleh pernyataan yang diungkapkan oleh petugas kesehatan wilayah kerja puskesmas Grabag II Magelang bahwa pendistribusian tablet $\mathrm{Fe}$ terhadap ibu hamil telah dilaksanakan tetapi diperoleh gambaran tentang ketidakpatuhan ibu hamil dalam mengkonsumsi tablet Fe.

Berdasarkan paparan di atas, maka perlu dilakukan penelitian tentang hubungan kepatuhan minum tablet $\mathrm{Fe}$ dengan anemia ibu hamil di wilayah kerja Puskesmas Grabag II Kabupaten Magelang.

\section{Rumusan Masalah}

Berdasarkan fenomena masalah diatas maka rumusan masalah dalam penelitian ini adalah : "Adakah hubungan antara kepatuhan minum tablet Fe dengan anemia ibu hamil di wilayah kerja Puskesmas Grabag II Kabupaten Magelang ?"

\section{Tujuan Penelitian}

Tujuan Umum

Diketahui hubungan antara kepatuhan minum tablet Fe dengan anemia ibu hamil di wilayah kerja Puskesmas Grabag II Kabupaten Magelang.

Tujuan Khusus

a. Diketahui karakteristik ibu hamil di wilayah kerja Puskesmas Grabag II Kabupaten Magelang berdasarkan umur dan paritas.

b. Diketahui kepatuhan minum tablet $\mathrm{Fe}$ pada ibu hamil di wilayah kerja Puskesmas Grabag II Kabupaten Magelang.

c. Diketahui anemia ibu hamil di wilayah kerja Puskesmas Grabag II Kabupaten Magelang

d. Diketahui keeratan hubungan antara kepatuhan minum tablet $\mathrm{Fe}$ dengan status anemia ibu hamil di wilayah kerja Puskesmas Grabag II Kabupaten Magelang

\section{Manfaat Penelitian}

\section{Manfaat Teoritis}

Hasil penelitian ini dapat digunakan dalam pengembangan ilmu kebidanan dan dapat dijadikan referensi bagi peneliti selanjutnya di bidang kesehatan ibu dan khususnya masalah kepatuhan minum tablet Fe.

Manfaat Praktis

a. Bagi Bidan

Sebagai bahan masukan bagi puskesmas untuk meningkatkan kepatuhan ibu hamil mengkonsumsi tablet $\mathrm{Fe}$ sehingga dapat menurunkan angka kejadian anemia pada ibu hamil di wilayah kerja Puskesmas Grabag II Magelang

b. Bagi lbu Hamil

Bagi ibu hamil atau masyarakat dapat menambah pengetahuan ibu mengenai pentingnya mengkonsumsi suplemen tablet zat besi secara teratur sesuai anjuran petugas kesehatan dalam 
rangka pencegahan kejadian anemia ibu hamil

c. Bagi Peneliti

Sebagai bahan masukan dan sarana bagi penulis untuk meningkatkan wawasan dan pengetahuan tentang kepatuhan ibu hamil minum tablet $\mathrm{Fe}$ dan masalah anemia pada ibu hamil, serta menambah pengalaman dalam menerapkan ilmu yang telah didapatkan selama masa perkuliahan khususnya dalam pelaksanaan penelitian. d. Bagi Penelitian Selanjutnya

Sebagai bahan referensi untuk melakukan penelitian selanjutnya yang berhubungan dengan anemia pada ibu hamil

\section{METODE PENELITIAN}

Penelitian ini merupakan penelitian kuantitatif korelasional analitik dengan pendekatan cross sectional. Kerangka kosep penelitiannya adalah :

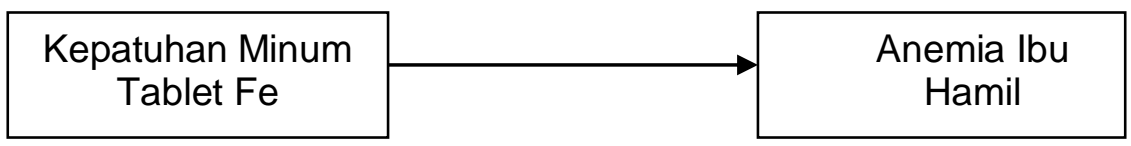

\section{Gambar 1. Kerangka Konsep}

Hipotesis dalam penelitian ini adalah "ada hubungan antara kepatuhan minum tablet $\mathrm{Fe}$ dengan anemia ibu hamil". Desain penelitiannya adalah :

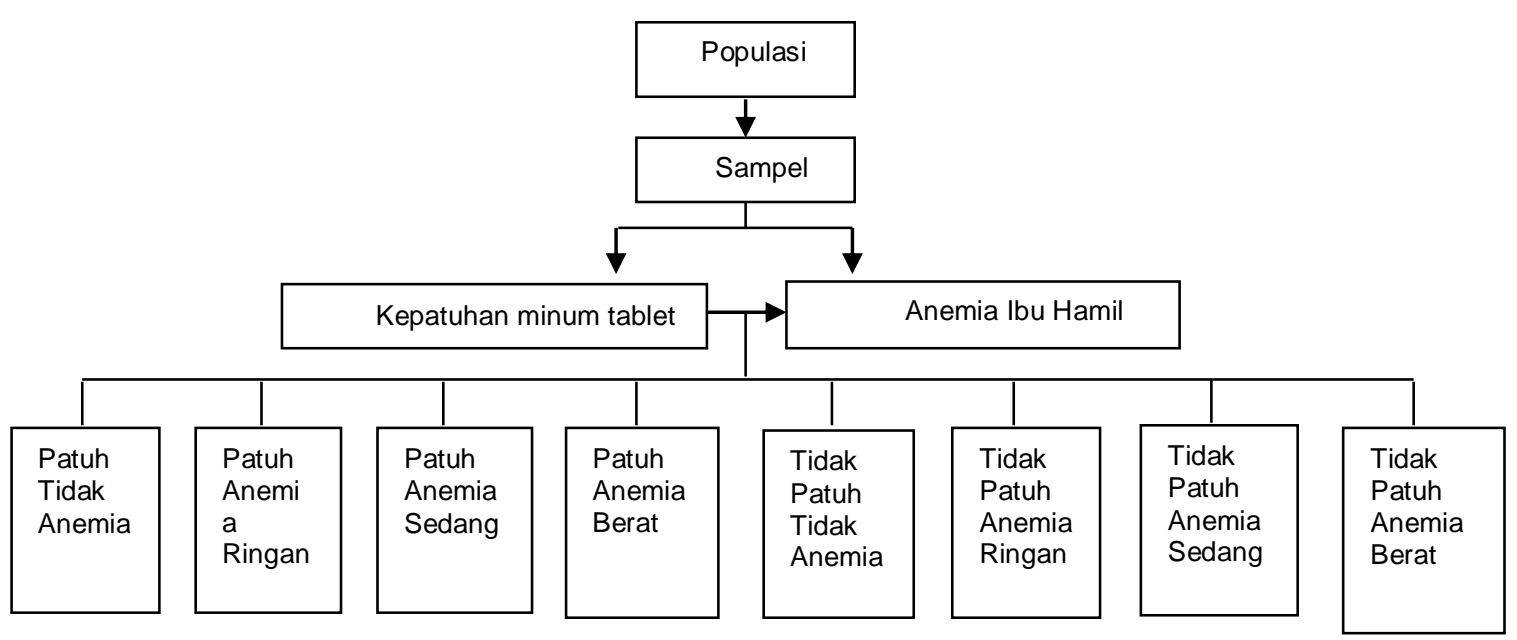

Populasi dalam penelitian ini adalah semua ibu hamil yang telah mendapat 90 tablet $\mathrm{Fe}$ yang ada di wilayah kerja puskesmas Grabag II Kabupaten Magelang sampai bulan Juni 2013 yaitu sebanyak 380 responden. Sampel diambil berdasarkan kriteria inklusi dan eksklusi. Kriteria inklusi dalam penelitian ini adalah :

a. Ibu hamil tinggal di wilayah kerja puskesmas Garabag II Kabupaten Magelang

b. Ibu hamil yang telah mendapatkan tablet Fe selama 90 hari

c. Ibu hamil bersedia diperiksa kadar haemoglobinnya.

Sedangkan kriteria eksklusinya adalah:

a. Ibu hamil dalam keadaan sakit (TBC, malaria dan perdarahan) b. Ibu hamil dengan kegawatdaruratan obstetrik.

Teknik sampling dalam penelitian ini menggunakan purposive sample. Perhitungan besar sampel dengan menggunakan rumus proporsi sebagai berikut :

$$
n=\frac{\left\{Z_{1-\alpha / 2} \sqrt{(2 P(1-P))}+Z_{1-\beta} \sqrt{(P 1(1-P 1))+P 2(1-P 2)}\right\}^{2}}{(P 1-P 2)^{2}}
$$

Hasil perhitungan besar sampel yang didapat yaitu 134 responden. Teknik pengumpulan data, data dalam penelitian ini menggunakan data primer dan data sekunder. Data primer diperoleh dengan menggunakan kuesioner yang berisi pernyataan tentang kepatuhan ibu minum 
tablet Fe dan data sekunder diperoleh dari kohort ibu hamil puskesmas Grabag II Kabupaten Magelang. Uji validitas dilakukan dengan uji korelasi menggunakan rumus Pearson Product Moment dengan taraf kesalahan $5 \%$ dan taraf signifikasi $95 \%$. Reliabilitas dalam penelitian ini menggunakan internal consistency, hasil yang diperoleh dianalisis dengan menggunakan rumus alpha cronbach. Reliabilitas kuesioner dilakukan dengan membandingkan antara $r$ alfa dengan $r$ tabel, jika $r$ alfa lebih besar dari $r$ tabel $(r$ alfa $>r$ tabel) maka kuesioner dinyatakan reliable. Data yang di dapat diolah dengan analisis univariat dan bivariat. Analisis bivariat menggunakan rumus Chi Square (x2).
Untuk mengetahui tingkat keeratan hubungan, digunakan Coefisien Contingensi (CC). Kriteria keeratan hubungan dengan menggunakan koefisien kontingen sebagai berikut :

a. $0,00-0,19=$ hubungan sangat lemah

b. $0,20-0,39=$ hubungan lemah

c. $0,40-0,59=$ hubungan cukup kuat

d. $0,60-0,79=$ hubungan kuat

e. $0,80-1,00=$ hubungan sangat kuat

\section{HASIL DAN PEMBAHASAN}

- Karakteristik ibu hamil di wilayah kerja Puskesmas Grabag II Kabupaten Magelang

Tabel 1. Distribusi frekuensi ibu hamil berdasarkan karakteristik umur ibu hamil di wilayah kerja Puskesmas Grabag II Kabupaten Magelang

\begin{tabular}{clcc}
\hline No & \multicolumn{1}{c}{ Kategori } & Frekuensi & Persentase (\%) \\
\hline $\mathbf{1}$ & Reproduksi sehat & 120 & 89,6 \\
$\mathbf{2}$ & Tidak reproduksi sehat & 14 & 10,4 \\
& Jumlah & 134 & 100 \\
\hline
\end{tabular}

Berdasarkan hasil penelitian diperoleh data sebagian besar ibu hamil merupakan ibu hamil dengan usia reproduksi sehat (20-35 tahun) yaitu sebanyak 120 responden $(89,6 \%)$, hal ini menunjukkan bahwa umur ibu berada pada umur aman untuk hamil dan bersalin, karena menurut Wiknjosastro (2006) umur hamil pada usia terlalu muda (<20 tahun) tidak atau belum siap untuk memperhatikan lingkungan yang diperlukan untuk pertumbuhan janin ${ }^{10}$. Disamping itu akan terjadi kompetisi makanan antar janin dan ibunya sendiri yang masih dalam pertumbuhan dan adanya pertumbuhan hormonal yang terjadi selama kehamilan. Sedangkan ibu hamil diatas 30 tahun lebih cenderung mengalami anemia, hal ini disebabkan karena pengaruh turunnya cadangan zat besi dalam tubuh akibat masa fertilisasi.

- Karakteristik paritas ibu hamil di wilayah kerja Puskesmas Grabag II Kabupaten Magelang

Tabel 2. Distribusi frekuensi ibu hamil berdasarkan karakteristik paritas ibu hamil di wilayah kerja Puskesmas Grabag II Kabupaten Magelang

\begin{tabular}{|c|c|c|c|}
\hline No & Kategori & Frekuensi & Persentase (\%) \\
\hline 1 & Primipara & 81 & 60,4 \\
\hline 2 & Multipara & 51 & 38,1 \\
\hline \multirow[t]{2}{*}{3} & Grandemultipara & 2 & 1,5 \\
\hline & Jumlah & 134 & 100 \\
\hline
\end{tabular}


Berdasarkan hasil tabulasi data diperoleh hasil sebagian besar ibu hamil merupakan ibu hamil dengan paritas primipara yaitu sebanyak 81 responden (60,4\%).

Paritas menurut Wiknjosastro (2006) adalah wanita yang pernah melahirkan bayi yang dapat hidup $(\text { viable })^{10}$, sedangkan menurut Bobak dkk (2005) paritas adalah jumlah kehamilan yang menghasilkan janin hidup, bukan jumlah janin yang dilahirkan.
Seorang ibu yang sering hamil mempunyai risiko mengalami anemia pada kehamilan berikutnya apabila tidak memperhatikan kebutuhan nutrisi. Adapun seorang ibu yang hamil pertama kali berisiko pula karena belum memiliki pengalaman sehingga berdampak pada perilaku yang berkaitan dengan asupan nutrisi. ${ }^{11}$

- Kepatuhan minum tablet Fe pada ibu hamil di wilayah kerja Puskesmas Grabag II Kabupaten Magelang

Tabel 3. Distribusi frekuensi ibu hamil berdasarkan kepatuhan minum tablet Fe pada ibu hamil di wilayah kerja Puskesmas Grabag II Kabupaten Magelang

\begin{tabular}{|c|c|c|c|}
\hline No & Kategori & Frekuensi & Persentase (\%) \\
\hline 1 & Patuh & 33 & 24,6 \\
\hline 2 & Tidak patuh & 101 & 75,4 \\
\hline & Jumlah & 134 & 100 \\
\hline
\end{tabular}

Berdasarkan hasil penelitian diperoleh hasil sebagian besar ibu hamil tidak patuh minum tablet $\mathrm{Fe}$ yaitu sebanyak 101 responden (75,4\%). Kepatuhan menurut Siregar adalah tingkat ketepatan perilaku seorang individu dengan nasehat medis atau kesehatan dan menggambarkan penggunaan obat sesuai dengan petunjuk pada resep serta mencakup penggunaannya pada yang benar. ${ }^{13}$

Kepatuhan seorang ibu hamil untuk mengkonsumsi Tablet Tambah Darah memang sangat penting dilaksanakan dan menurut DeaMaeyer E.M, wanita hamil harus diyakinkan tentang pentingnya zat besi bagi kesehatan ibu dan janin yang sedang dikandung. Kepatuhan mengkonsumsi Tablet Tambah Darah merupakan salah satu upaya penting dalam mencegah dan menanggulangi anemia, khususnya anemia kekurangan zat besi. ${ }^{12}$

- Anemia ibu hamil di wilayah kerja Puskesmas Grabag II Kabupaten Magelang

Tabel 4. Distribusi frekuensi anemia ibu hamil di wilayah kerja Puskesmas Grabag II Kabupaten Magelang

\begin{tabular}{|c|c|c|c|}
\hline No & Kategori & Frekuensi & Persentase (\%) \\
\hline 1 & Normal & 47 & 35,1 \\
\hline 2 & Ringan & 83 & 61,9 \\
\hline \multirow[t]{2}{*}{3} & Sedang & 4 & 3 \\
\hline & Jumlah & 134 & 100 \\
\hline
\end{tabular}


Hasil penelitian menunjukkan sebagian besar ibu hamil dengan status anemia ringan yaitu sebanyak 83 responden (61,9\%). Anemia dalam kehamilan menurut Proverawati dan Asfuah (2009) didefinisikan sebagai penurunan kadar hemoglobin kurang dari $11 \mathrm{~g} / \mathrm{dl}$ selama kehamilan pada trimester 1 dan ke-3, dan kurang dari $10 \mathrm{~g} / \mathrm{dl}$ selama post partum dan trimester 2, sedangkan menurut Saifuddin (2006) anemia dalam kehamilan adalah kondisi dengan kadar hemoglobin di bawah $11 \mathrm{gr} \%$ pada trimester 1 dan 3 atau kadar <10,5gr\% pada trimester 2, nilai batas tersebut dan perbedaannya dengan kondisi wanita tidak hamil, terjadi karena hemodilusi, terutama pada trimester dua.

Anemia pada kehamilan yang disebabkan kekurangan zat besi mencapai kurang lebih 95\%. Terjadinya peningkatan volume darah mengakibatkan hemodilusi atau pengenceran darah sehingga kadar $\mathrm{Hb}$ mengalami penurunan dan terjadi anemia. ${ }^{14}$

Anemia ditandai dengan rendahnya konsentrasi hemoglobin $(\mathrm{Hb})$ atau hematocrit nilai ambang batas (referensi) yang disebabkan oleh rendahnya produksi sel darah merah (eritrosit) dan Hemoglobin $(\mathrm{Hb}), \quad$ meningkatnya kerusakan eritrosit (hemolysis) atau kehilangan darah yang berlebihan. Defisiensi $\mathrm{Fe}$ berperan besar dalam kejadian anemia, namun defisiensi zat gizi lainnya, kondisi nongizi, dan kelainan genetic (herediter) juga memainkan peran terhadap anemia. ${ }^{15}$

$\begin{array}{lcr}\text { Kategori } & \text { anemia } & \text { menurut } \\ \text { Proverawati dan Asfuah } & \text { dengan } \\ \text { melakukan } & \text { pemeriksaan } & \text { kadar }\end{array}$
Hemoglobin $(\mathrm{Hb})$ dalam darah dengan kategori yaitu normal jika kadar $\mathrm{Hb}>11$ gr\%, anemia ringan jika kadar $\mathrm{Hb} 9-10$ gr\%, anemia sedang jika kadar $\mathrm{Hb} 7-8$ gr\%, dan anemia berat jika kadar $\mathrm{Hb}<7$ gr\% Anemia berat. ${ }^{16}$

- Tabulasi silang hubungan antara kepatuhan minum tablet Fe dengan anemia ibu hamil di wilayah kerja Puskesmas Grabag II Kabupaten Magelang

Tabel 5. Tabulasi silang hubungan antara kepatuhan minum tablet Fe dengan anemia ibu hamil di wilayah kerja Puskesmas Grabag II Kabupaten Magelang

\begin{tabular}{|c|c|c|c|c|c|c|c|c|c|c|}
\hline \multirow[t]{3}{*}{ Kepatuhan } & \multicolumn{6}{|c|}{ Anemia } & \multirow{2}{*}{\multicolumn{2}{|c|}{ Jumlah }} & \multirow{3}{*}{$\begin{array}{c}\chi^{2} \\
\text { hitung }\end{array}$} & \multirow{3}{*}{ CC } \\
\hline & \multicolumn{2}{|c|}{ Normal } & \multicolumn{2}{|c|}{ Ringan } & \multicolumn{2}{|c|}{ Sedang } & & & & \\
\hline & f & $\%$ & $f$ & $\%$ & $f$ & $\%$ & $f$ & $\%$ & & \\
\hline Patuh & 30 & 90,9 & 3 & 9,1 & 0 & 0 & 33 & 100 & 59,964 & 0,556 \\
\hline Tidak Patuh & 17 & 16,8 & 80 & 79,2 & 4 & 4 & 101 & 100 & & \\
\hline
\end{tabular}

Hasil tabulasi silang hubungan antara kepatuhan minum tablet Fe dengan anemia ibu hamil di wilayah kerja Puskesmas Grabag II Kabupaten Magelang diperoleh hasil dari 33 ibu hamil yang patuh minum tablet $\mathrm{Fe}$ sebagian besar kadar hemoglobinnya normal atau tidak mengalami anemia sebanyak 30 responden (90,9\%), sedangkan dari 101 ibu hamil yang tidak patuh minum tablet Fe sebagian besar mengalami anemia ringan sebanyak 80 responden $(79,2 \%)$, sedangkan hasil hitung hubungan antara kepatuhan minum tablet Fe dengan status anemia ibu hamil di wilayah kerja Puskesmas Grabag II Kabupaten Magelang dengan menggunakan uji Chi Square Test didapatkan $x 2$ hitung sebesar 59,964 maka 59,964 > 5,991 (x2 tabel) dan $p$ value 0,000 , sehingga ada hubungan antara kepatuhan minum tablet Fe dengan anemia ibu hamil di wilayah kerja Puskesmas Grabag II Kabupaten Magelang, sedangkan untuk mengetahui 
keeratan hubungan kepatuhan minum tablet Fe dengan anemia ibu hamil terlihat pada Contingency Coefficient adalah 0,556 dan hubungan tersebut kuat karena nilainya berada pada rentang $0,40-0,59$.

Kepatuhan mengkonsumsi tablet zat besi diukur dari ketepatan jumlah tablet yang dikonsumsi, ketepatan cara mengkonsumsi tablet zat besi, frekuensi konsumsi perhari. Dosis pemberian zat besi dibedakan atas dosis pencegahan dan dosis pengobatan. Dosis pencegahan diberikan kepada kelompok sasaran tanpa pemeriksaan kadar Hb. Dosis yang dianjurkan untuk ibu hamil sampai masa nifas adalah sehari satu tablet $(60 \mathrm{mg}$ besi elemental) dan $0,25 \mathrm{mg}$ asam folat. Berturut-turut selama minimal 90 hari masa kehamilannya sampai 42 hari setelah melahirkan. Dengan pertimbangan bahwa sebagian besar ibu hamil mengalami anemia, maka dilakukan pemberian preparat Fe sebanyak 90 tablet pada ibu-ibu hamil di Puskesmas. Dosis pengobatan diberikan pada sasaran $(\mathrm{Hb}<$ ambang batas) yaitu bila kadar $\mathrm{Hb}<$ $11 \mathrm{gr} \%$ pemberian menjadi 3 tablet sehari selama 90 hari kehamilannya. ${ }^{17}$

Selain itu, pola konsumsi makanan juga dapat mempengaruhi anemia ibu hamil karena juga berhubungan dengan kepatuhan minum tablet Fe. Pola konsumsi makanan adalah susunan makanan yang dikonsumsi setiap hari untuk memenuhi kebutuhan tubuh dalam satu hidangan lengkap (Almatsier, 2009). Kejadian anemia sering dihubungkan dengan pola makanan yang rendah kandungan zat besinya serta makanan yang dapat memperlancar dan menghambat absorpsi zat besi.

$$
\text { Hasil penelitian ini juga }
$$

menunjukkan meskipun ibu hamil patuh dalam minum tablet $\mathrm{Fe}$ namun masih mengalami anemia ringan. $\mathrm{Hal}$ ini dimungkinkan karena faktor lain, seperti ibu tidak patuh dalam cara minum tablet $\mathrm{Fe}$, yaitu dengan cara minum $\mathrm{Fe}$ menggunakan air teh. Faktor lain juga dapat disebabkan karena faktor usia, karena berdasarkan hasil penelitian menunjukkan terdapat 14 (10,4\%) ibu hamil dengan usia reproduksi tidak sehat. Umur ideal untuk kehamilan yang risikonya rendah adalah pada kelompok umur 20-35 tahun. Berdasarkan laporan Riset Kesehatan Dasar (Riskesdas) tahun 2010, perempuan yang mengalami kehamilan pada usia berisiko tinggi (35 tahun ke atas) $4,6 \%$ tidak pernah memeriksakan kehamilan, dan yang berusia $<20$ tahun 5,1\% memeriksakan kehamilan pada dukun.

Menurut Kristiyanasari, selain dengan mengkonsumsi tablet $\mathrm{Fe}$, untuk meningkatkan kadar $\mathrm{Hb}$ dalam darah dapat juga dikonsumsi melalui makanan yang mengandung zat besi. Untuk memenuhi kebutuhan ibu hamil harus memenuhi kebutuhan zat besinya yaitu sekitar 45-50 mg/hari. Kebutuhan itu dapat dipenuhi dari makanan yang kaya akan zat besi seperti daging berwarna merah, hati, ikan, kuning telur, sayuran berdaun hijau, kacang-kacangan, tempe, roti dan sereal. Besi nonhemoglobin harus dikonsumsi bersama buah-buahan yang mengandung vitamin $\mathrm{C}$ untuk meningkatkan penyerapan.

Untuk meningkatkan kepatuhan pada ibu hamil perlu terus dilakukan penyuluhan baik individu maupun secara berkelompok. Untuk lebih memudahkan dan melakukan pendekatan pada ibu hamil maka sebaiknya penyuluhan kepada individu lebih diutamakan agar pesanpesan yang disampaikan mudah diterima dan dipahami serta dilaksanakan oleh ibu hamil.

\section{KESIMPULAN}

Hasil penelitian hubungan kepatuhan minum tablet $\mathrm{Fe}$ dengan anemia ibu hamil di wilayah kerja Puskesmas Grabag II Kabupaten Magelang maka peneliti menyimpulkan :

- Ibu hamil usia reproduksi sehat (2035 tahun) yaitu sebanyak 120 responden $(89,6 \%)$ dan dengan paritas primigravida yaitu sebanyak 81 responden $(60,4 \%)$.

- Ibu hamil yang tidak patuh minum tablet Fe sebanyak 101 responden (75,4\%).

- Ibu hamil dengan status anemia ringan sebanyak 83 responden $(61,9 \%)$ 
- Ada hubungan kepatuhan minum tablet $\mathrm{Fe}$ dengan status anemia ibu hamil di wilayah kerja Puskesmas Grabag II Kabupaten Magelang dengan $p$ value $0,000(0,000<0,05)$ dan hubungan tersebut cukup kuat karena nilai Contingency Coefficient 0,556

\section{SARAN}

Setelah peneliti melakukan penelitian tentang hubungan kepatuhan minum tablet Fe dengan anemia ibu hamil di wilayah kerja Puskesmas Grabag II Kabupaten Magelang, peneliti memiliki saran sebagai berikut :

- Untuk Bidan

Disarankan untuk memberikan penyuluhan lebih intensif kepada ibu hamil karena dari hasil penelitian ini masih ditemukan ibu tidak patuh. Penyuluhan yang diberikan terutama tentang cara mengkonsumsi tablet Fe berkaitan dengan jumlah tablet $\mathrm{Fe}$ yang harus dihabiskan maupun cara minum yang benar tablet Fe agar zat besi dapat diserap tubuh lebih maksimal dan dapat menurunkan angka kejadian anemia pada ibu hamil.

- Untuk Peneliti

Peneliti dapat meningkatkan wawasan dan pengetahuan tentang kepatuhan ibu hamil minum tablet $\mathrm{Fe}$ dan masalah anemia pada ibu hamil, serta menambah pengalaman dalam menerapkan ilmu.

- Untuk lbu Hamil

Disarankan untuk mengikuti dan mematuhi instruksi (petunjuk) dari petugas kesehatan tentang jumlah tablet Fe yang diminum dan cara minum tablet $\mathrm{Fe}$, agar kadar hemoglobin ibu meningkat $\geq 11 \mathrm{gr} \%$.

- Untuk Penelitian Selanjutnya

Diharapkan penelitian ini dapat dijadikan acuan untuk penelitian yang berhubungan dengan anemia dalam kehamilan.

\section{DAFTAR PUSTAKA}

1. Depkes RI. Profil Kesehatan Indonesia 2008. Jakarta : Depkes RI; 2009.

2. Kemenkes RI. Modul Pelatihan Konseling Dan Tes Sukarela HIV (Voluntary Counseling And Testing = VCT). Jakarta: Kemenkes; 2013

3. Dinkes Provinsi Jawa Tengah. Profil Kesehatan Provinsi Jawa Tengah. Semarang : Dinkes; 2012

4. Departemen Gizi dan Kesehatan Masyarakat. Gizi dan Kesehatan Masyarakat. Jakarta : Raja Grafindo Persada; 2011.

5. Soebroto. Anemia. Jogjakarta : Bangkit; 2009

6. Fanny, Mustamin, Dewi dan Kartini. Pengaruh Pemberian Tablet Fe terhadap Kadar Hemoglobin lbu Hamil di Puskesmas Tamamaung Tahun 2011. Media Gizi Pangan, Vol.XIII, Edisi 1, $2012: 7$ - 11; 2012.

7. Nirdayani. Pengaruh Kepatuhan Mengkonsumsi Tablet Fe Terhadap Kadar Hemoglobin $(\mathrm{Hb})$ Ibu Hamil di Wilayah Kerja Puskesmas Kota Kabupaten Aceh Tengah Tahun 2012. Medan : USU Digital Library; 2012.

8. Gibney et al. Gizi Kesehatan Masyarakat. Jakarta : EGC; 2009.

9. Anggreni, E. Kepatuhan Ibu Hamil Dalam Mengkonsumsi Tablet Zat Besi Terhadap Tingkat Kejadian Anemia Di Puskesmas Pekan Heran Kabupaten Indragiri Hulu Tahun 2008. Sripsi. Universitas Sumatera Utara; 2008.

10. Riskesdas. Riset Kesehatan Dasar Laporan Nasional 2010. Jakarta : BPPK; 2010.

11. Wiknjosastro. IImu Kebidanan. Jakarta : Bina Pustaka Sarwono Prawirohardjo; 2006.

12. Saifuddin, Abdul Bari. Buku Acuan Nasional Pelayanan Maternal dan Neonatal. Jakarta : Yayasan Bina Pustaka Sarwono Prawirohardjo; 2006.

13. Hernawati. Hubungan Kepatuhan Konsumsi Tablet Tambah Darah dengan Status Anemia Ibu Hamil di Desa Kotaraja Kecamatan Sikur Kabupaten Lombok Timur. Available from 
<http://www.lpsdimataram.com>.

[Acessed : 10 September 2013]; 2013.

14. Siregar. Psikologi Keperawatan Dan Kesehatan. Jakarta : Salemba Medika; 2006

15. Varney. Buku Ajar Asuhan Kebidanan Volume 1. Jakarta : EGC; 2007.

16. Departemen Gizi dan Kesehatan Masyarakat. Gizi dan Kesehatan
Masyarakat. Jakarta : Raja Grafindo Persada; 2011.

17. Proverawati dan Asfuah. Gizi untuk Kebidanan. Jakarta : Nuha Medika; 2009.

18. Manuaba. IImu Kebidanan, Penyakit Kandungan dan KB. Jakarta : EGC; 2012. 